\title{
RANTAI PASOK DAN LOGISTIK UDANG VANAME DI DAERAH PRODUKSI DI INDONESIA
}

\section{Supply Chain and Logistic of Vannamei Shrimp In Production Areas of Indonesia}

\author{
*Achmad Zamroni, Risna Yusuf dan Tenny Apriliani \\ Balai Besar Riset Sosial Ekonomi Kelautan dan Perikanan \\ Gedung BRSDM KP I Lt. 4 \\ Jalan Pasir Putih Nomor 1 Ancol Timur, Jakarta Utara, Indonesia \\ Telp: (021) 64711583 Fax: 64700924
}

Diterima tanggal: 23 November 2020 Diterima setelah perbaikan: 19 November 2021

Disetujui terbit: 20 Desember 2021

\begin{abstract}
ABSTRAK
Rantai pasok udang vanamei di daerah produksi di Indonesia tidak selalu sama dan dipengaruhi oleh ketersediaan fasilitas pembenihan sampai dengan unit pengolahan ikan (UPI). Konsekuensinya, jenis dan jumlah biaya logistik bervariasi antara daerah satu dengan yang lain. Riset ini bertujuan untuk; a) mengidentifikasi rantai pasok udang vanamei di daerah produksi, b) menganalisis permasalahan dalam rantai pasok udang vanamei, dan c) merumuskan sistem logistik udang vanamei. Riset dilakukan selama tahun 2019 di beberapa provinsi yang memproduksi udang vanamei yaitu Jawa Timur, Jawa Barat, Bali, Nusa Tenggara Barat, dan Sulawesi Selatan. Riset ini menggunakan data primer dan data sekunder. Data primer diperoleh melalui wawancara dengan menggunakan topik data kepada 12 responden pembenihan, 4 responden UPI, 40 responden pembudidaya udang vanamei, dan 10 pedagang/pengumpul. Data sekunder diperoleh dari laporan hasil riset, data statistik, dan publikasi ilmiah lainnya. Data dianalisis secara deskriptif untuk menggambarkan rantai pasok, pola logistik, dan permasalahan yang terjadi dalam rantai pasok. Hasil analisis menggambarkan bahwa rantai pasok udang vanamei di Indonesia bisa digolongkan menjadi 3 bagian, yaitu pasokan (bahan baku dan produksi), distribusi (pedagang besar, pedagang kecil, dan pengecer), dan konsumen (pasar lokal, hotel/ restoran/catering -HOREKA- dan UPI). Permasalahan rantai pasok udang vanamei dari produsen benih sampai ke konsumen akhir telah menyebabkan produksi tidak efisien dan berimplikasi pada peningkatan biaya. Secara faktual, ada disparitas stok benih antar daerah dan kebutuhan pemenuhan stok udang di beberapa cold storage. Logistik udang vanamei menggunakan hampir semua jenis moda transportasi yaitu transportasi udara (pesawat terbang), transportasi darat (sepeda motor, mobil bak terbuka, truk biasa, truk kontainer) dan transportasi laut (kapal antar pulau dan antar negara). Sistem logistik udang belum efisien mengingat pengadaan induk udang vanamei masih diimpor dari negara lain oleh beberapa perusahaan pembenihan, dan benih ini harus menyuplai seluruh wilayah Indonesia.
\end{abstract}

Kata kunci: budi daya; rantai pasok; sistem logistik, udang

\section{ABSTRAK}

The supply chain of vannamei shrimp in production areas of Indonesia is different in each area. It depends on the availability of hatchery facilities and the fish processing unit (UPI). Consequently, the types and logistic costs vary among regions. This research aims to: a) identify the supply chain of vannamei shrimp in the production area, b) formulate a general pattern of the logistic system of vannamei shrimp, and c) analyze the problems in the supply chain of vannamei shrimp. This research was conducted in 2019 in East Java, West Java, Bali, West Nusa Tenggara, and South Sulawesi where those provinces produce vannamei shrimp. This research employs primary and secondary data. Primary data were collected through interviews with five hatchery respondents, four UPI respondents, 40 vannamei shrimp farmers, and seven collectors/traders. Secondary data were obtained from research reports, statistical data, and other scientific publications. Data were analyzed descriptively to describe the supply chain, logistic patterns, and problems that occur in the supply chain. The results illustrate that vannamei supply chain in Indonesia can be classified into three parts: raw materials and production, distribution (wholesalers, small traders, and retailers) and consumers (local markets, hotel/restaurant/catering, 
and processing plants). The problem of vannamei supply chain from hatcheries to the final consumers has resulted in inefficient production and has been implicated in increased costs. Eventually, there are disparities in shrimp juvenile stocks between regions and the need to fulfill shrimp stocks in several cold storages Logistic system of vannamei shrimp utilizes almost all types of transportation modes: air transport (cargo planes), land transportation (motorbikes, trucks, cargo trucks) and water transportation (inter-island and inter-country cargo ships). The logistics system of vannamei was inefficient considering the procurement of vannamei shrimp broodstocks have always been imported from other countries by several hatchery companies, and shrimp juveniles produced need to be distributed to all-around Indonesia.

Keywords: aquaculture; supply chain; logistic system, shrimp

\section{PENDAHULUAN}

Kebijakan Kementerian Kelautan Perikanan (KKP) terkait komoditas udang dari hulu ke hilir dapat dilihat dari kebijakan tata kelolakelolanya dari hulu ke hilir, yaitu mulai dari hulu di pengadaan induk udang vanamei, hingga ke hilir pada saat pemasaran hasil produkkepada konsumen. Sistem logistik sebagai salah satu penentu daya saing sektor kelautan dan perikanan tidak hanya berfungsi untuk penyimpanan dan distribusi ikan tetapi juga berfungsi untuk mempertahankan kualitas ikan dari hulu hingga sampai ke tangan konsumen. Kebijakan KKP dalam mempertahankan kualitas produk perikanan diantaranya melalui penjaminan mutu dalam bentuk sertifikasi cara budi daya ikan yang baik (CBIB) sebagai salah satu upaya meningkatkan daya saing produk di pasar regional, nasional dan internasional.

Komoditas udang merupakan salah satu komoditas perikanan yang paling banyak diminati dan memiliki nilai jual yang tinggi di pasar domestik dan internasional. Udang juga merupakan komoditas potensial dan merupakan komoditas revitalisasi perikanan yang nilai ekspornya di berbagai negara selalu mengalami peningkatan dari tahun ke tahun. Data BPS (2019) menunjukkan tren volume ekspor dari seluruh produk perikanan berfluktuasi namun volume ekspor udang meningkat dari tahun 2012 sampai 2018 dengan rata-rata nilai pertumbuhan sebesar $6,64 \%$. Pada sisi produksi, jenis udang yang berasal dari budidaya tambak yang paling banyak diproduksi secara nasional adalah jenis udang vanamei. Jumlah produksi udang vanamei adalah 476.455 ton atau sebesar $71 \%$ dari total produksi udang. Jumlah produksi vanamei ini disusul dengan produksi udang windu sebesar 128.655 ton atau $19 \%$, udang api-api sebanyak
25.324 ton atau $4 \%$, dan sisanya adalah udang lainnya dan udang putih masing-masing sebesar 18.582 ton (3\%) dan 17.969 ton (3\%). Jika dilihat berdasarkan wilayah, pulau Jawa memiliki jumlah produksi udang sebanyak 217.988 ton atau sebesar $32,7 \%$ dengan produksi vanamei sebesar 144.873 ton. Produksi vanamei di Jawa ini tertinggi dibandingkan wilayah atau provinsi lainnya; wilayah Sumatera memiliki produksi udang sebanyak 160.013 ton atau $24 \%$ dengan produksi vanamei sebesar 136.748 ton; wilayah Bali-Nusa Tenggara memiliki produksi udang sebanyak 120.910 atau $18,1 \%$ dengan produksi vanamei sebesar 120.721 ton; wilayah Sulawesi memiliki produksi udang sebanyak 112.392 ton atau $16,9 \%$ dengan produksi vanamei sebesar 67.681 ton; wilayah lainnya yang tersebar di beberapa provinsi yang ada di Kalimantan, Maluku dan Papua memiliki produksi udang masing-masing sebanyak 50.679 ton $(7,6 \%)$ dan 4.984 ton $(0,7 \%)$ dan 1.504 ton (PDS, 2019).

Pada sisi produksi, banyak permasalahan yang sering dihadapi oleh pembudidaya diantaranya terbatasnya ketersediaan serta distribusi induk dan benih unggul, tingginya harga pakan yang menyebabkan hasil dari budidaya ikan masih belum maksimal, serangan hama dan penyakit ikan/udang, serta adanya pencemaran yang mempengaruhi kualitas lingkungan perikanan budidaya. Permasalahan tersebut yang menyebabkan rendahnya daya saing komoditas udang vanamei Indonesia. Hal tersebut diperparah dengan masih dipasoknya induk udang vanamei dari luar negeri seperti Hawaii, Florida dan Amerika Latin. Hal tersebut menunjukkan bahwa Indonesia harus terus berupaya untuk menghasilkan induk unggul udang vanamei yang mampu bersaing dengan induk impor baik dari sisi kecepatan pertumbuhan maupun ketahanan terhadap penyakit. 
Tantangan berikutnya adalah terkait pembenihan udang vanamei dari sisi lokasi dan aksesibilitas. Lokasi pembenihan udang terpusat pada lokasi tertentu saja karena pertimbangan kondisi perairan dan lingkungan. Hal tersebut mengakibatkan peningkatan biaya distribusi dan transportasi benih menuju lokasi budidaya. Permasalahan lain yang sering dihadapi adalah tumpang tindihnya pemanfaatan lahan, terbatasnya prasarana saluran irigasi, tingginya harga pakan, serangan hama dan penyakit ikan/udang, serta adanya pencemaran yang mempengaruhi kualitas lingkungan perikanan budidaya.

Permasalahan tata niaga udang vanamei adalah ketergantungan yang tinggi pada permintaan pasar. Udang vanamei merupakan komoditas ekspor sehingga permintaan negara pengimpor menjadi penentu dalam distribusi udang termasuk dalam penentuan harga. Perusahaan cold storage atau UPI yang juga merupakan eksportir mempunyai kedudukan dan peran yang strategis dalam sistem pemasaran udang. Mereka merupakan pihak yang menguasai informasi pasar ekspor dan berperan dalam penentuan harga beli udang dari tingkat pedagang dan petani tambak. Di samping itu, pembangunan infrastruktur yang belum merata di berbagai sentra tambak udang serta lokasi tambak yang berada jauh dari pusat perdagangan menambah tantangan logistik yang lebih besar untuk mendistribusikan udang. Biaya logistik terutama untuk pemasaran yang dikeluarkan oleh pelaku usaha relatif masih tinggi, khususnya biaya distribusi (melalui laut, darat dan udara) (Deswati et al., 2020).

Berdasarkan kondisi di atas, dapat dilihat bahwa masih ada permaslahan pada proses rantai pasok udang vanamei di Indonesia, diantaranya: distribusi barang dari daerah produksi ke daerah konsumsi atau pemasaran, perbedaan infrastruktur antara wilayah, serta perbedaanskala usaha tambak. Oleh karena itu, berbagai upaya dilakukan untuk meningkatkan daya saing komoditas udang vanamei Indonesia, salah satunya dengan memperbaiki manajemen rantai pasok komoditas udang. Manajemen rantai pasokan merupakan integrasi proses bisnis dari pengguna akhir melalui pemasok yang menyediakan produk, layanan, dan informasi yang menambah nilai bagi pelanggan dan pemangku kepentingan lainnya (Lambert et al., 1998). Manajemen rantai pasok dicirikan oleh kontrol yang didasarkan pada jaringan dan integrasi proses antar fungsi lintas fungsi, geografis dan organisasi (Van Hoek, 1998).
Industri udang vanamei di Indonesia memerlukan kajian sebagai landasan ilmiah untuk melihat anatomi permasalahan dalam rangka memperbaiki tata kelola dan menemukan solusi. Memetakan permasalahan agribisnis udang vanamei sangat penting untuk mencari sumber masalah terutama pada rantai pasok. Makalah ini akan fokus pada rantai pasok udang vanamei di daerah sentra produksi dan pemasaran di Indonesia dan permasalahan-permasalahannya. Oleh karena itu, riset ini secara spesifik bertujuan untuk: a) mengidentifikasi rantai pasok udang vaname idi daerah produksi udang vanamei, b) menganalisis permasalahan dalam rantai pasok udang vanamei, dan c) merumuskan sistem logistik udang vanamei.

\section{METODOLOGI}

\section{Lokasi dan Waktu Penelitian}

Penelitian ini dilakukan dari bulan Januari sampai dengan Desember 2019. Lokasi penelitian merupakan representasi dari sentra-sentra produksi budi daya udang vanamei di wilayah Jawa dan luar Jawa yaitu Provinsi DKI Jakarta sebagai daerah pemasaran, Kabupaten Buleleng (Provinsi Bali), Kabupaten Lombok Timur dan Kabupaten Sumbawa (Provinsi Nusa Tenggara Barat), Kota Surabaya dan Kabupaten Banyuwangi (Provinsi Jawa Timur), Indramayu (Provinsi Jawa Barat), Kabupaten Pinrang dan Kota Makassar (Provinsi Sulawesi Selatan).

\section{Jenis dan Metode Pengambilan Data}

Data yang digunakan dalam penelitian ini adalah data primer dan data sekunder. Data primer dikumpulkan dengan menggunakan metode survei terhadap sampel yang mewakili seluruh populasi yang dipilih dengan metode purposive random sampling. Survei ini dilengkapi dengan kuesioner terstruktur sebagai instrumen dalam pengumpulan data. Sampel responden sudah ditentukan terhadap responden kunci yaitu 12 responden hatchery (pembenihan), 4 responden UPI, 40 responden pembudi daya udang vanamei, dan 10 pedagang/pengumpul. Wawancara mendalam dilakukan untuk menelusuri lebih detil terhadap sistem rantai pasok dan distribusi udang baik lokal maupun antar wilayah. Responden yang mewakili daerah produksi (pembenihan dan pembudi daya) diperoleh dari Kabupaten Indramayu, Kabupaten Pinrang, Kabupaten Banyuwangi, Kabupaten Sumbawa, Kabupaten Lombok Timur, dan 
Kabupaten Buleleng. Sementara itu, responden yang mewakili daerah pemasaran diperoleh dari lokasi DKI Jakarta, Surabaya, dan Makassar. Data sekunder terdiri data statistik perikanan, data ekspor udang vanamei, laporan penelitian, jurnal dan dokumen terkait yang dikumpulkan dari instansi yang berwenang dan serta dokumen yang terkait dengan topik penelitian.

\section{Metode Analisis}

Metode analisis yang digunakan dalam penelitian ini menggunakan teori manajemen rantai pasok/supply chain management (Champion \& Fearne, 2001). Manajemen rantai pasok yang dilakukan dengan cara pemetaan pelaku, pemetaan proses, pemetaan alur produk, pemetaan pengetahuan dan alur informasi, serta pemetaan volume produk, jumlah pelaku dan lapangan kerja. Inti dari pendekatan manajemen rantai pasok dalam penelitian ini hanya dibatasi pada aliran produk dan informasi yang diharapkan dapat menjembatani permintaan konsumen dan hubungan antara pelaku di dalam sistem pemasaran. Hubungan rantai pasok diharapkan tercipta secara alamiah dan hasilnya bermanfaat bagi pembeli dan penjual, sehingga aspek-aspek sosial seperti kepercayaan (trust), transfer informasi, dan kemampuan belajar akan mempengaruhi kinerja, pengembangan dan keberhasilan rantai nilai. Tahapan pendekatan manajemen rantai pasok udang dalam penelitian ini sebagai sebagai berikut: 1) mengidentifikasi rantai pasok udang vanamei; 2) mengidentifikasi profil rantai pasok termasuk di dalamnya pelaku dalam sistem rantai pasok dan penyedia jasa logistik; 3) mengukur kinerja rantai pasok komoditas udang di lokasi penelitian.

Informasi-informasi mengenai manajemen rantai pasok tersebut disajikan secara deskriptif. Metode deskriptif digunakan untuk menyederhanakan data dalam bentuk yang lebih mudah dipahami (Nazir, 1988). Khusus untuk data kualitatif, informasi yang telah terkumpul dalam penelitian ini dikelompokkan, kemudian disusun dan dianalisis secara deskriptif kualitatif. Pada riset ini, analisis deskriptif digunakan untuk mendeskripsikan dan mendefinisikan pelaku dan penyedia jasa logistik udang vanamei yang meliputi jaringan, pelaku, penyedia jasa logistik, tata niaga dan tata Kelola. Pada rantai pasok udang vanamei, langkah awal yang perlu dilakukan adalah mendefinisikan 5 (lima) komponen yang membentuk pelaku dan penyedia jasa logistik udang vanamei. Kelima komponen tersebut adalah jaringan, pelaku, penyedia jasa logistik, tata niaga, tata kelola. Jaringan yang dimaksud adalah jaringan yang menjamin ketersediaan dan kelancaran arus barang (benih, pakan, saprokan, dan produk udang) dari daerah asal barang ke hubungan nasional (UPI) secara efektif. Pelaku udang vanamei terdiri dari pengusaha nasional dan internasional, namun pelaku pada industri udang vanamei masih didominasi oleh pelaku nasional. Secara umum, pelaku yang ada dalam industri udang nasional adalah perusahaan pembenihan, pabrik pakan, penyedia saprokan, pembudi daya udang (tradisional, semi intensif dan intensif), pengumpul (skala kecil maupun besar). Penyedia jasa logistik pada industri udang vanamei terdiri dari cold storage, container, dan sarana transportasi (mobil pick up, truck, kapal, dan pesawat) serta forwarder. Tata niaga udang vanamei di Indonesia termasuk dalam kategori pasar bebas, yang pangsa pasarnya meliputi pakan, benih, saprokan dan produk udang vanamei. Tata kelola udang vanamei di dalam negeri harus mengikuti aturan-aturan yang dikeluarkan oleh organisasi perdagangan dunia atau World Trade Organization (WTO) yang terkait dengan aturan tarif maupun sertifikasi dan keamanan pangan suatu produk (Tabel 1). Selain itu, metode deskripsi juga digunakan untuk menjelaskan permasalahan yang terjadi pada rantai pasok dan logistik udah vanamei. Selain itu, pola logistik yang menjadi temuan dalam riset ini dijelaskan secara deskriptif yang meliputi proses, alat transportasi, maupun destinasi disetiap simpul

Jaringan logistik dan rantai pasok komoditas unggulan ekspor akan menjangkau pusat-pusat produksi dan pusat-pusat pertumbuhan untuk menjamin kelancaran arus barang dari daerah asal barang ke pelabuhan Hub-Internasional secara efektif dan efisien. Model konseptual sistem logistik udang vanamei yang dibangun pada riset ini didasarkan pada kondisi terkini pada lokasi riset, yang dianggap mewakili daerah produksi dan daerah pemasaran udang vanamei. Tahapan yang dilakukan dalam menyusun model ini adalah sebagai sebagai berikut: 1) mengidentifikasi profil rantai pasok udang vanamei mulai dari pembenihan sampai dengan unit pengolahan ikan; 2) membuat rancangan model rantai pasok udang vanamei; 3) merancang model trade logistic udang vanamei; 4) merancang model freight logistic udang vanamei, dan; 5) merancang sistem informasi untuk udang vanamei. 
Tabel 1. Pelaku dan Penyedia Jasa Logistik Udang Vaname, 2019

Table 1. Businessmen and Logistic Service Provider of Vaname Shrimp Logistics Services, 2019

\section{Komoditas Udang Vaname/The Commodity of Vaname Shrimp}

Jaringan/Networks Jaringan umum yang menjamin ketersediaan dan kelancaran arus barang (benih, pakan dan saprokan dan produk udang) dari daerah asal barang ke hubungan nasional (UPI) secara efektif dan efisien/A general network that ensures the availability and smooth flow of goods (shrimp juveniles, feed, production facilities and equipment, shrimp products) from the origin of goods to national relations of processing units conducted effectively and efficiently.

Pelaku/Actors Pengusaha nasional dan internasional; dominasi jaringan oleh pelaku nasional (Perusahaan pembenihan, pabrik pakan, penyedia saprokan, pembudi daya udang, (tradisional, semi intensif dan intensif), pengumpul kecil dan pengumpul besar)/ National and international investors; network domination by national actors (hatchery companies, feed factories, suppliers of fish production facilities and equipment, shrimp farmers (traditional, semi-intensive and intensive), small collectors and large scale collectors)

Penyedia Jasa logistik/Logistic Service Provider

Pengusaha nasional dan internasional (cold storage, container, sarana transportasi (pick up, truck, kapal, pesawat))/ National and International businesses (cold storage, container, transportation (pick-ups, trucks, ships, airplanes)

Tata Niaga/Trade System Pasar bebas (Pakan, benih, saprokan, udang)/ Free markets Tata Kelolal (feeds, shrimp juveniles, fish production facilities and equipment, shrimp products) Mengikuti aturan WTO (Aturan tarif, keamanan pangan)/ Governance Following rules and regulations of the World Trade Organization (WTO) (Tariffs, food safety)

\section{HASIL DAN PEMBAHASAN}

\section{Rantai pasok udang vanamei di daerah produksi}

Profil rantai pasok udang vanamei di Indonesia dapat digambarkan melalui 4 bidang, yaitu: kinerja, jaringan, tata niaga dan tata kelola. Bidang kinerja dibagi menjadi 3 kriteria yaitu jangkauan layanan, ketersediaan dan harga. Pada riset ini, jangkauan layanan yang diidentifikasi adalah menjangkau layanan produksi yang meliputi pembenihan dan pembesaran sampai pada unit pengolahan ikan/udang (UPI). Kriteria ketersediaan didefinisikan bahwa rantai pasok ini dapat menjamin ketersediaan udang di UPI untuk kebutuhan ekspor. Kriteria harga didefinisikan bahwa rantai pasok menjamin kestabilan harga benih dan udang serta meminimalkan disparitas harga antar daerah produsen (pembenihan dan pembesaran) (Tabel 2).

Pada bidang jaringan diindikasikan pada 4 kriteria yaitu mata rantai, pasokan, penyaluran dan pengendalian. Kriteria mata rantai didefinisikan bahwa pada level pembudi daya udang vanamei skala semi intensif dan intensif harus berbadan hukum, sementara pembudi daya udang vanamei skala tradisional harus terdaftar atau teregistrasi ke lembaga terkait, misalnya Dinas Perikanan kabupaten. Kriteria pasokan dalam rantai pasok udang vanamei didefinisikan sebagai optimalisasi dan ekstensifikasi produksi benih dan udang dengan memanfaatkan tambak tradisional untuk semi intensif dan intensif. Selain itu, perlu dibentuk pusat-pusat pembenihan (sentra penghasil benih) yang mempunyai induk di daerah potensial. Pada kriteria penyaluran, rantai pasok udang vanamei diharapkan dapat menjangkau distribusi benih udang vanamei ke seluruh wilayah NKRI dengan metode rayonisasi, demikian halnya dengan distribusi udang ke UPI atau pabrik dengan menggunakan metode yang sama. Pada kriteria pengendalian, rantai pasok udang vanamei diharapkan dapat mengendalikan kualitas dan kuantitas benih dan udang vanamei dengan cara memastikan pembenihan dan budi daya udang vanamei dengan menggunakan metode CPIB dan CBIB. Memperketat pelaporan data yang terkait dengan pembenihan dan pembesaran udang serta meregistrasi pelaku usaha (pembudi daya, pedagang kecil dan pedagang besar).

Pada bidang tata niaga dibagi menjadi 5 kriteria yaitu target konsumen, kesempatan dan 
Tabel 2. Profil sistem rantai pasok udang vanamei, 2019

Table 2. Profile of Vannamei Supply Chain, 2019

\begin{tabular}{|c|c|c|}
\hline Bidang/ Scope & Kriteria/ Criteria & Pembahasan/ Discussions \\
\hline \multirow[t]{4}{*}{ Kinerja/Performance } & $\begin{array}{l}\text { Jangkauan layanan/ } \\
\text { Service Areas }\end{array}$ & $\begin{array}{l}\text { - Menjangkau pelayanan dari produksi } \\
\text { (pembenihan dan pembesaran) sampai ke UPI/ } \\
\text { Reaching services from production (hatchery } \\
\text { and farming) to processing units }\end{array}$ \\
\hline & Ketersediaan/Availability & $\begin{array}{l}\text { - Menjamin ketersediaan udang di UPI untuk } \\
\text { kebutuhan ekspor/ Ensuring the availability of } \\
\text { shrimp for export at processing units }\end{array}$ \\
\hline & Harga/Price & $\begin{array}{l}\text { - Menjamin kestabilan harga benih dan udang/ } \\
\text { Menjamin kestabilan harga benih dan udang/ } \\
\text { Ensuring the stability of prices of shrimp juvenile } \\
\text { and shrimp products. }\end{array}$ \\
\hline & & $\begin{array}{l}\text { - Meminimalkan disparitas harga antar daerah } \\
\text { produsen (pembenihan dan pembesaran)/ } \\
\text { Minimizing price disparities between production } \\
\text { area (hatchery and farming) }\end{array}$ \\
\hline \multirow[t]{3}{*}{$\begin{array}{l}\text { Jaringan/ } \\
\text { network }\end{array}$} & Mata rantai/chain & $\begin{array}{l}\text { - Mata rantai pasokan dan distribusi udang } \\
\text { tergolong pendek/ supply chain and distribution } \\
\text { of shrimp supply are relatively concise. }\end{array}$ \\
\hline & & $\begin{array}{l}\text { - Pembudi daya semi internsif dan intensif harus } \\
\text { berbadan hukum sedangkan pembudi daya } \\
\text { tradisional harus terdaftar/ Semi-intensive and } \\
\text { intensive shrimp farmers must held a legal } \\
\text { entity, while traditional shrimp farmers must be } \\
\text { registered. }\end{array}$ \\
\hline & Pasokan/supply & $\begin{array}{l}\text { - Optimalisasi dan ekstensifikasi produksi benih } \\
\text { dan udang dengan memanfaatkan tambak } \\
\text { tradional untuk semi intensif dan intensif/ } \\
\text { Optimalizing and extensification of shrimp } \\
\text { juveniles and shrimp production by utilizing } \\
\text { traditional shrimp ponds for semi-intensive and } \\
\text { intensive farming method. }\end{array}$ \\
\hline
\end{tabular}

- Pendirian pusat-pusat pembenihan yang mempunyai induk di daerah potensial/ Establishing hatchery centers with broodstocks in potential areas.

Penyaluran/Distribution - Jangkauan distribusi benih ke seluruh wilayah Indonesia dengan metode rayonisasi/ Distribution coverage of shrimp juvenile to the entire Indonesian area by rayonization method.

- Jangkauan distribusi udang ke UPI atau pabrik dengan metode rayonisasi/ Distribution coverage of shrimp to processing units by rayonization method.

Pengendalian/Control - Memastikan implementasi Cara Budi daya Ikan yang Baik (CBIB) dan Cara Pmbenihan Ikan yang Baik (CPIB) di daerah produksi/ Ensuring implementation of Indonesian Good Aquaculture Practices and Indonesian Good Hatchery Practices in production areas

- Pelaporan data yang terkait pembenihan dan pembesaran udang/ Reporting data related to hatchery and shrimp farming.

- Registrasi pelaku usaha (pembudi daya, pedagang kecil dan pedagang besar)/ Registration of business actors (shrimp farmers, small scale traders and large scale traders). 


\begin{tabular}{|c|c|c|}
\hline Bidang/ Scope & Kriteria/ Criteria & Pembahasan/ Discussions \\
\hline \multirow[t]{7}{*}{$\begin{array}{l}\text { Tata/ niaga/trade } \\
\text { system }\end{array}$} & $\begin{array}{l}\text { Target konsumen/target } \\
\text { consumers }\end{array}$ & $\begin{array}{l}\text { - UPI, Hotel Restoran dan Katering (HOREKA), } \\
\text { dan konsumen rumah tangga/ Processing units, } \\
\text { hotel-restaurant-catering (HOREKA), household } \\
\text { consumers }\end{array}$ \\
\hline & $\begin{array}{l}\text { Kesempatan dan } \\
\text { keberlangsungan usaha/ } \\
\text { Business Opportunity and } \\
\text { Sustainability }\end{array}$ & $\begin{array}{l}\text { - Terbuka bagi pelaku usaha kecil dan menengah } \\
\text { dan jaminan kelangsungan usaha dengan } \\
\text { memberikan profit margin yang wajar/ Open } \\
\text { for small and medium enterprises and ensuring } \\
\text { business sustainability by providing a reasonable } \\
\text { profit margin. }\end{array}$ \\
\hline & Aspek legal//legal aspect & $\begin{array}{l}\text { - Pembudi daya semi intensif dan intensif, } \\
\text { pedagang besar dan UPI harus berbadan } \\
\text { hukum sedangkan pembudi daya tradisional, } \\
\text { pedagang kecil dan pengecer harus terdaftar/ } \\
\text { semi intensive and intensive shrimp farmers, } \\
\text { wholesalers, and shrimp processing units must } \\
\text { held a legal entity, while traditional shrimp } \\
\text { farmers, small scale traders, retailers must be } \\
\text { registered. }\end{array}$ \\
\hline & Hubungan/Relationship & $\begin{array}{l}\text { - Hubungan kerjasama yang } \\
\text { menguntungkan/ A mutual cooperation }\end{array}$ \\
\hline & & $\begin{array}{l}\text { - Koordinasi dengan baik antar pelaku usaha } \\
\text { untuk menjamin efektifitas dan efisiensi/ } \\
\text { Good coordination among actors to ensure } \\
\text { effectiveness and efficiency }\end{array}$ \\
\hline & Harga/Price & $\begin{array}{l}\text { - Menjamin keuntungan yang memadai dan } \\
\text { berkeadilan bagi setiap pelaku usaha pada } \\
\text { rantai pasok udang/ Ensuring adequate and } \\
\text { equitable profits for every actor in the shrimp } \\
\text { supply chain. }\end{array}$ \\
\hline & & $\begin{array}{l}\text { - Menjamin kestabilan harga dan disparitas harga } \\
\text { antar daerah seminimal mungkin/ Ensuring } \\
\text { price stability and minimizing price disparities } \\
\text { between regions. }\end{array}$ \\
\hline \multirow[t]{3}{*}{$\begin{array}{l}\text { Tata Kelola/ } \\
\text { Governance }\end{array}$} & Kewenangan/Authority & $\begin{array}{l}\text { - Kewenangan pemerintah pusat (KKP, } \\
\text { Kementrian Perdagangan) dan pemerintah } \\
\text { daerah: perijinan, pengawasan dan pembinaan } \\
\text { yang sesuai dengan fungsinya/ The authority } \\
\text { of central government (MMAF and Ministry } \\
\text { of Trade) and local government which in } \\
\text { accordance to their function: licensing, } \\
\text { supervision, and guidance. }\end{array}$ \\
\hline & Manajemen/management & $\begin{array}{ll}\text { Manajemen } & \text { professional/professional } \\
\text { management } & \end{array}$ \\
\hline & Subsidi/Subsidy & - $\quad$ tidak ada subsidi/No subsidies \\
\hline
\end{tabular}

keberlangsungan usaha, aspek legal, relationship, dan harga. Target konsumen pada rantai pasok udang vanamei diperuntukkan kepada UPI, hotel-restoran dan katering (HOREKA), dan konsumen rumah tangga. Kriteria kesempatan dan keberlangsungan usaha dimaksudkan bahwa rantai pasok udang vanamei terbuka bagi pelaku usaha kecil dan menengah serta menjamin kelangsungan usaha dengan memberikan profit margin yang wajar. Kriteria aspek legal mensyaratkan kepada pembudi daya udang vanamei semi intensif dan intensif, pedagang besar dan UPI harus berbadan hukum sedangkan pembudi daya tradisional, pedagang kecil dan pengecer harus terdaftar. Kriteria relationship akan mendorong rantai pasok udang vanamei ini kepada hubungan kerja sama yang sama-sama menguntungkan, terkoordinasi dengan baik antar pelaku usaha untuk menjamin efektifitas dan efisiensi (Elizabeth, 2019). Kriteria harga pada rantai pasok diharapkan dapat 
menjamin keuntungan yang memadai dan berkeadilan bagi setiap pelaku usaha pada rantai pasok udang dan menjamin kestabilan harga dan disparitas antar daerah seminimal mungkin. Bidang tata kelola mempunyai 3 kriteria yaitu kewenangan, manajemen, dan subsidi. Pada kriteria kewenangan, pemerintah pusat yang mempunyai wewenang dalam tata kelola industriudang vanameiadalah KKP dengan Kementerian Perdagangan. Sementara itu, pemerintah daerah mempunyai kewenangan untuk perijinan, pengawasan dan pembinaan. Manajemen yang profesional menjadi syarat mutlak dalam menciptakan rantai pasok yang efisien. Tidak ada subsidi dalam menjalankan industri udang vanamei mengingat produk ini merupakan produk prioritas ekspor.

Berdasarkan profil udang vanamei di atas, rantai pasok udang vanamei di Indonesia bisa digolongkan menjadi 3 bagian yaitu pasokan, distribusi, dan konsumen. Pasokan dikelompokkan menjadi 2 yaitu pasokan bahan baku dan pasokan produksi. Pada pasokan bahan baku terdiri dari importir induk udang vanamei yang masih disuplai dari Hawaii, produsen dan pedagang pakan, obatobatan dan lain-lain. Pasokan produksi udang vanamei terdiri dari perusahaan pembenihan yang menghasilkan benih udang vanamei, pembudi daya udang vanamei yang berskala tradisional, semi intensif dan intensif. Kelompok distribusi terdiri dari pedagang besar, pedagang kecil, dan pengecer. Sementara konsumen udang vanamei terdiri dari pasar lokal, HOREKA dan UPI atau cold storage (Gambar 1). Gambar 1 menunjukkan bahwa rantai pasok udang vanamei di Indonesia tergolong masih pendek.

Pemasok, distributor, pengecer atau konsumen yang terhubung dengan tanda panah menggambarkan aliran material di setiap tahap. Rantai pasok yang sifatnya tertutup menggambarkan adanya perubahan dalam konsumen dan perusahaan, serta membuka ruang terbuka baru bagi pelaku rantai pasok (Masi et al., 2017). Pada tahap manufacturing mewakili operasi tradisional yang mana bahan baku tiba dari pemasok eksternal; material berubah dalam beberapa cara untuk menciptakan persediaan barang. Tahap pada bagian hilir lainnya seperti distribusi dan ritel juga menambah suatu nilai terhadap material (Liu et al., 2013).

\section{Kinerja rantai pasok udang vanamei}

Kinerja rantai pasok terdiri atas 2 (dua) indikator yaitu efektifitas dan efisiensi. Indikator efektifitas yaitu untuk melihat ketersediaan pasokan yang ada di daerah produsen udang vanamei. Hal ini penting juga untuk mengukur agregat pendapatan pada skala mikro (Kanji \& Barrientos, 2002). Berdasarkan hasil analisis diketahui bahwa Provinsi Nusa Tenggara Barat (NTB) merupakan daerah pemasok udang terbesar dengan efektifitas kinerja sebesar 94\%, selanjutnya daerah Jawa Barat sebesar $82 \%$, Jakarta sebesar $45 \%$ dan Sulawesi Selatan sebesar $30 \%$. Penentuan besaran pasokan udang tersebut dilihat dari produksi udang pada lokasi tersebut dan dibandingkan dengan

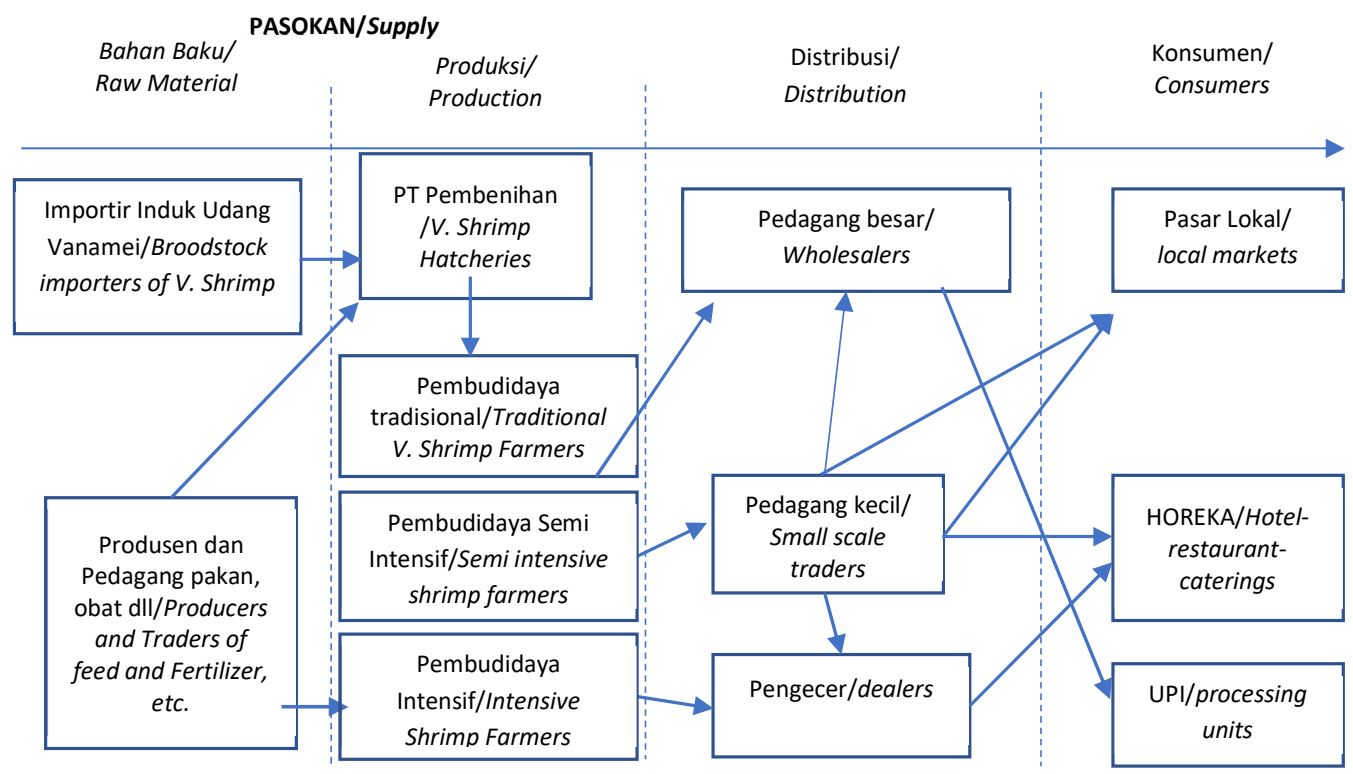

Gambar 1. Rantai Pasok Udang Vanamei, 2019

Figure 1. Vannamei Supply Chain, 2019 
permintaan udang baik untuk skala industri (UPI) maupun permintaan konsumsi domestik. Indikator efisiensi dilihat dari 2 (dua) indikator yaitu disparitas harga dan margin harga. Disparitas harga yang terdiri dari disparitas harga antar waktu dan disparitas harga antar daerah. Berdasarkan analisis yang dilakukan pada disparitas harga antar waktu ternyata Provinsi NTB tidak memiliki disparitas harga antar waktu. Sementara itu, Provinsi Bali merupakan daerah yang memiliki disparitas harga antar waktu terbesar yaitu sebesar $16 \%$. Namun, Batker \& Genciano (2003) mengingatkan bahwa harga tidak selalu mencerminkan biaya produksi, sehingga hal ini sering kali yang menyebabkan kegagalan pasar. Disparitas harga antar daerah terlihat bahwa dibandingkan dengan daerahdaerah lainnya, daerah NTB memiliki disparitas harga tertinggi yaitu sebesar 67\% (Tabel 3).

Pada indikator efisiensi yang terkait dengan margin harga dimana konsumen akhirnya adalah pasar lokal, pedagang kecil merupakan pelaku usaha yang memiliki margin harga terkecil yaitu sebesar $3 \%$ yang disusul dengan pengecer sebesar $22 \%$. Pada rantai dimana tujuan akhir pasar adalah UPI, pedagang kecil memiliki margin harga sebesar $4,3 \%$. Persentase ini kecil dibanding simpul lain dalam rantai pasok udang untuk konsumen akhir UPI, sedangkan pedagang pengumpul memiliki margin harga terbesar yaitu $12,5 \%$ dibanding simpul lainnya. Meski demikian, Tajerin et al. (2015) menyatakan bahwa pasar distribusi ikan dan komoditas lainnya masih mempunyai karakteristik pasar oligopoli dimana terdapat satu pelaku usaha yang dominan dengan beberapa pelaku usaha sebagai pengikut atau follower. Kondisi ini menyebabkan biaya-biaya yang diciptakan dalam sistem distribusi tidak dapat bersaing secara sempurna dan biaya-biaya ditentukan oleh pelaku yang dominan. Hal ini membutuhkan fungsi pengelolaan rantai pasok agar transparansi dan traceability dari produk dapat teraudit dengan baik (Song et al., 2019).

\section{Pola logistik udang vaname}

Dukungan kajian sistem logistik terhadap program KKP pada perikanan budidaya untuk komoditas udang sangat diperlukan agar mampu menjawab secara secara komprehensif tantangan dan permasalahan mulai dari aspek penanganan pasokan, produksi, distribusi dan konsumsi ikan sehingga menghasilkan sistem logistik yang efisien pada perikanan budidaya. Data dan informasi yang diperoleh dari kajian sistem logistik perikanan budidaya ini kemudian menjadi input bagi pemerintah untuk merumuskan kebijakan yang tepat. Pola logistik udang vanamei pada penelitian

Tabel 3. Kinerja Rantai Pasok Komoditas Udang vanamei di beberapa daerah produsen terpilih, 2019.

Table 3. Performance of Vannamei Supply Chain in Selected Production Centers, 2019

Indikator/Indicators Variabel/Variables Kinerja/Performances

Efektif/Effective Ketersediaan/Availability Efektifitas kinerja rantai pasok di NTB sebesar 94\%, Jawa Barat $82 \%$, Jakarta $45 \%$, Sulsel $30 \% /$ Shrimp supplies from West Nusa Tenggara, West Java, Jakarta and South Sulawesi were 94\%, 82\%, 45\% and $30 \%$, respectively.

\section{Efisien/Efficient}

Disparitas Harga/Price Disparitas Harga Antar Disparitas harga antar waktu di NTB adalah 0\%, Disparity Waktu/Price Disparities in Sulawesi Selatan 1\%, Bali 16\%/ Price disparities over time over time in West Nusa Tenggara, South Sulawesi and Bali was $0 \%, 1 \%$ and $16 \%$, respectively

Disparitas Harga Antar Daerah/price disparities $67 \%$ di NTB/ $67 \%$ in West Nusa Tenggara between regions

Margin Harga/Price Pasar lokal/local market

Margin harga untuk pedagang kecil adalah $3 \%$, pedagang pengumpul $12,5 \%$, pengecer $22 \%$ / Price margins of small-scale traders, middlemen and retailers were $3 \%, 12,5 \%$ and $22 \%$, respectively Unit Pengolahan Ikan Margin harga untuk pedagang kecil adalah 4,3\% (UPI)/Fish Processing sedangkan pengumpul sebesar $12,5 \% /$ Price Unit margins of small-scale traders and middlemen are $4,3 \%$ and $12,5 \%$, respectively. 
ini didasarkan pada kondisi terkini pada lokasi sampel yang merupakan representasi daerah produksi dan daerah pemasaran udang vanamei.

Selain itu, konsep sistem informasi yang dibangun untuk menginisiasi sistem informasi berbasis information and communication technology (ICT) untuk melihat akumulasi data udang vanamei dan disparitas supply dan demand udang vanamei dari masing-masing daerah produksi dan pemasaran udang vaname. Holmström \& Partanen (2014) mengeksplorasi implikasi digitalisasi yang dapat menawarkan peluang yang akan mengubah rantai pasok konvensional menuju rantai pasok inovatif. Miller (2018) pertimbangkan rantai pasok digital sebagai konsep dasar untuk membangun integrasi informasi ujung ke ujung dalam rantai pasok yang inovatif, dan persyaratan serta fungsi dari arah rantai pasok inovatif. Integrasi secara lokal dan keterhubungan secara global dalam sistem logistik nasional dilakukan melalui integrasi dan efisiensi jaringan logistik yang terdiri atas jaringan distribusi, jaringan transportasi, jaringan informasi, dan jaringan keuangan yang didukung oleh pelaku dan penyedia jasa logistik (Risna et al., 2020). Dengan demikian, jaringan sistem logistik dalam negeri dan keterhubungannya dengan jaringan logistik global akan menjadi kunci kesuksesan di era persaingan rantai pasok global (global supply chain), karena persaingan tidak hanya antar produk, antar perusahaan, namun juga antar jaringan logistik dan rantai pasok bahkan antar negara (Hadie \& Hadie, 2017).

Gambar 2 menggambarkan alur rantai pasok udang vanamei diawali dengan indukudang vanamei dari Hawai dan diimpor oleh beberapa pembenihan skala besar. Pembenihan-pembenihan tersebut tersebar di beberapa provinsi. Sedikitnya ada 6 provinsi yang ada pembenihan yang menghasilkan benih udang vanamei dan memiliki induk sendiri, yaitu Jawa Timur, Jawa Tengah, Nusa Tenggara Barat, Jawa Barat, Lampung, dan Banten. Benih udang vanamei dari pembenihan tersebut didistribusikan ke tambak (tradisional, semi intensif, intensif) baik dalam satu provinsi maupun ke provinsi lainnya. Udang dibudi dayakan di tambak tersebut selama kurang lebih 3 bulan, kemudian udang hasil panen dijual ke pedagang pengecer dan pedagang besar. Udang dari hasil tambak tradisional dibeli oleh pengecer atau pengumpul kecil, karena hasil panen memang lebih sedikit dibandingkan dengan hasil panen dari tambak intensif. Sementara itu, udang vanamei hasil panen dari tambak udang intensif dibeli oleh pedagang pengumpul besar. Pedagang pengumpul membeli udang tersebut dengan melakukan pemanenan sendiri bersama tim panen. Pedagang pengumpul kecil atau pengecer selanjutnya menjual udang tersebut ke konsumen rumah tangga dan hotel, restoran dan kafe (HOREKA). Sementara pedagang pengumpul besar menjual udang ke unit pengolahan ikan (UPI).

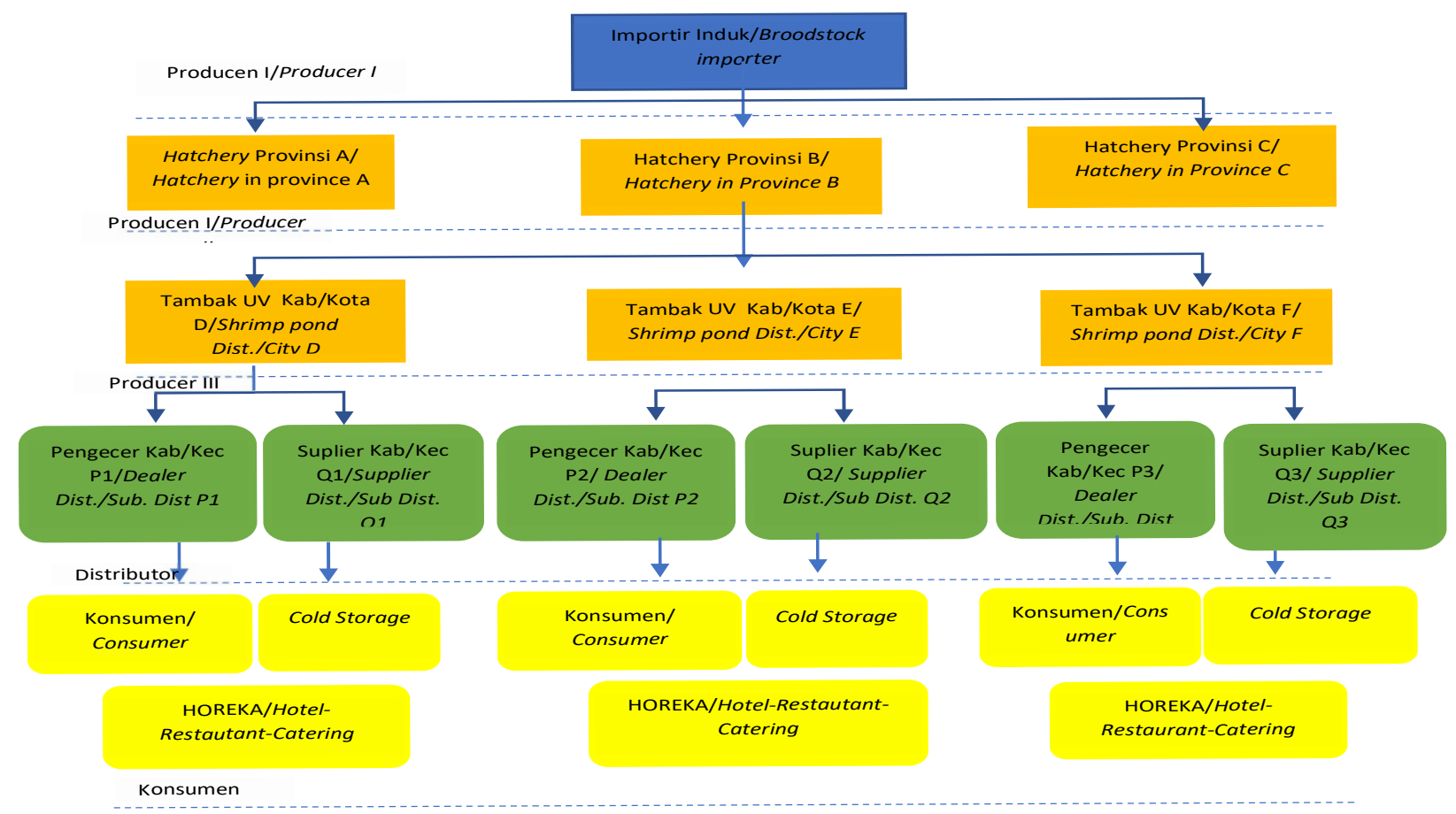

Gambar 2. Skema Trade logistik udang vanamei.

Figure 2. Trade Logistic Scheme of Vannamei Shrimp 
Berdasarkan Gambar 3, Freight logistic pada udang vanamei saat ini merujuk pada 5 titik utama yaitu bandara (internasional dan domestik), pelabuhan kapal niaga, dalam provinsi, dalam kabupaten/kota dan desa. Bandar udara internasional menjadi pintu masuk induk udang vanamei dari Hawaii yang selama ini masuk melalui Bandar Udara International Soekarno-Hatta dan Bandar Udara International Juanda - Surabaya. Pusat-pusat keluar masuk induk, benih udang dan udang dapat dijadikan sebagai klaster. Penciptaan klaster tersebut dapat berfungsi untuk memperkuat jaringan dan kemitraan antara pembudi daya udang dan pelaku usaha lainnya dalam rantai pasokan (Ha et al., 2013; Ramirez et al., 2018; Lee et al., 2018), yang saling terhubung secara geografis di bidang masing-masing dan saling melengkapi.
Induk-induk udang vanamei tersebut, setelah proses pemeriksaan di bea cukai bandara dan karantina ikan, didistribusikan ke pembenihan yang ada di provinsi DKI Jakarta dan Jawa Timur maupun di luar kedua provinsi tersebut. Distribusi induk udang vanamei dari bandar udara ke pembenihan di dalam provinsi menggunakan kendaraan truk atau mobil pick up (bak terbuka) yang sudah disiapkan cool box atau kotak yang dilengkapi pendingin atau es untuk menjaga kestabilan suhu selama perjalanan. Sementara distribusi induk udang vanamei ke pulau atau provinsi lain dilakukan dengan menggunakan pesawat terbang melalui bandar udara domestik.

Proses di pembenihan membutuhkan beberapa bulan sampai induk menghasilkan benih udang vanamei. Benih udang vanamei kemudian

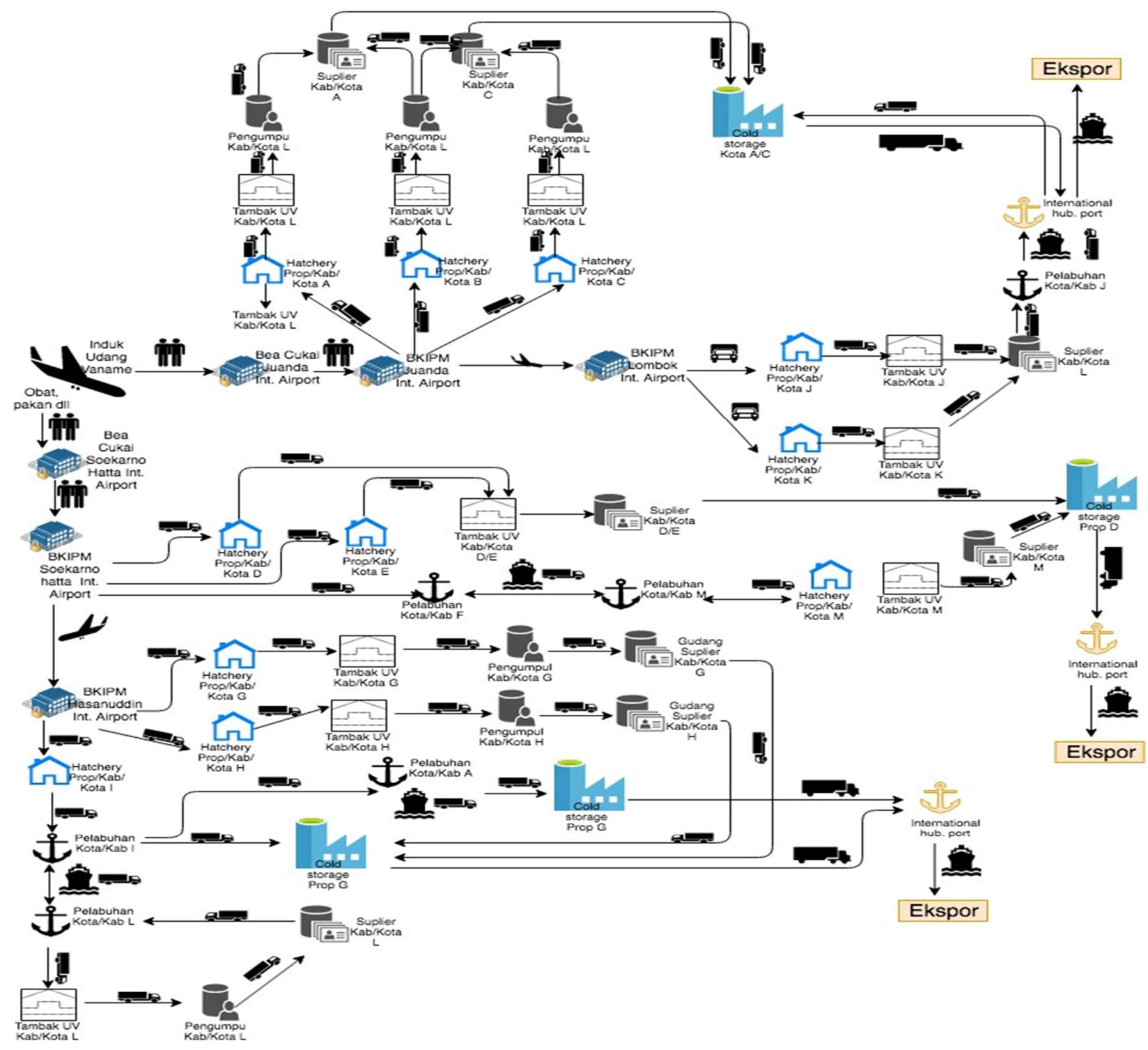

Gambar 3. Skema existing Freight logistic udang vaname, 2019

Figure 3. Existing Freight logistic Scheme of Vannamei Shrimp, 2019 
didistribusikan ke tambak-tambak udang di sekitar pembenihan dengan menggunakan mobil bak terbuka atau sepeda motor jika kebutuhan benih sedikit dan lokasi yang berdekatan dengan pembenihan. Distribusi benih ke kabupaten lain bahkan antar pulau dilakukan dengan menggunakan mobil baik terbuka yang sudah dilengkapi dengan fasilitas pendingin (es) untuk menjaga suhu selama perjalanan. Sementara itu, distribusi benih antar pulau dilakukan dengan menggunakan pesawat terbang atau mobil bak terbuka dengan menggunakan jasa kapal penyeberangan antar pulau.

Udang vanamei yang dibeli pengecer biasanya diperuntukkan pasar lokal yang dapat diangkut dengan menggunakan sepeda motor atau mobil bak terbuka dan langsung dibawa ke pasar - pasar ikan di daerah tersebut, atau dijual ke pengumpul yang lebih besar. Selanjutnya, dari pengumpul besar tersebut udang langsung disusun di dalam truk dengan menggunakan coolbox. Penyusunan dalam kendaraan truk tersebut biasanya membutuhkan waktu 1 hari sambil menunggu pengumpul-pengumpul kecil lain, kemudian dibawa ke cold storage yang berada di provinsi atau dekat dengan pelabuhan (hub. Internasional). Proses ini membutuhkan waktu yang bervariasi antara 1-4 hari tergantung jarak lokasi tambak dan cold storage. Apabila kedua lokasi tersebut berbeda pulau, maka pengiriman barang tetap menggunakan truk dan jasa kapal penyeberangan.

Gambar 4 menjelaskan secara singkat alur distribusi udang vanamei mulai dari induk udang vanamei, benih udang, sampai pada udang ukuran untuk konsumsi dan ekspor. Logistik udang vanamei menggunakan hampir semua jenis moda transportasi yaitu udara (pesawat terbang), darat (sepeda motor, mobil bak terbuka, truk biasa, truk), laut (kapal antar pulau dan antar negara). Gambar 4 juga memperjelas bahwa rantai distribusi udang vanamei dari mulai hasil panen sampai dengan konsumen akhir masih tergolong pendek, sehingga masih terjamin efisiensi waktu, biaya dan harga komoditas. Hal tersebut sama halnya yang dikatakan Govindan et al. (2015) bahwa jaringan tertutup pada rantai pasok dapat digunakan untuk memperbaiki nilai produk dengan berbagai dinamika volumenya. Namun demikian, secara faktual ada disparitas stok benih antar daerah dan kebutuhan pemenuhan stok udang di beberapa cold storage.

\section{Dinamika permasalahan dalam rantai pasok udang vaname}

Secara umum, permasalahan yang sering dihadapi oleh pembudi daya udang vanameiadalah tumpang tindihnya pemanfaatan lahan, terbatasnya prasarana saluran irigasi, keterbatasan serta distribusi induk dan benih unggul, harga pakan

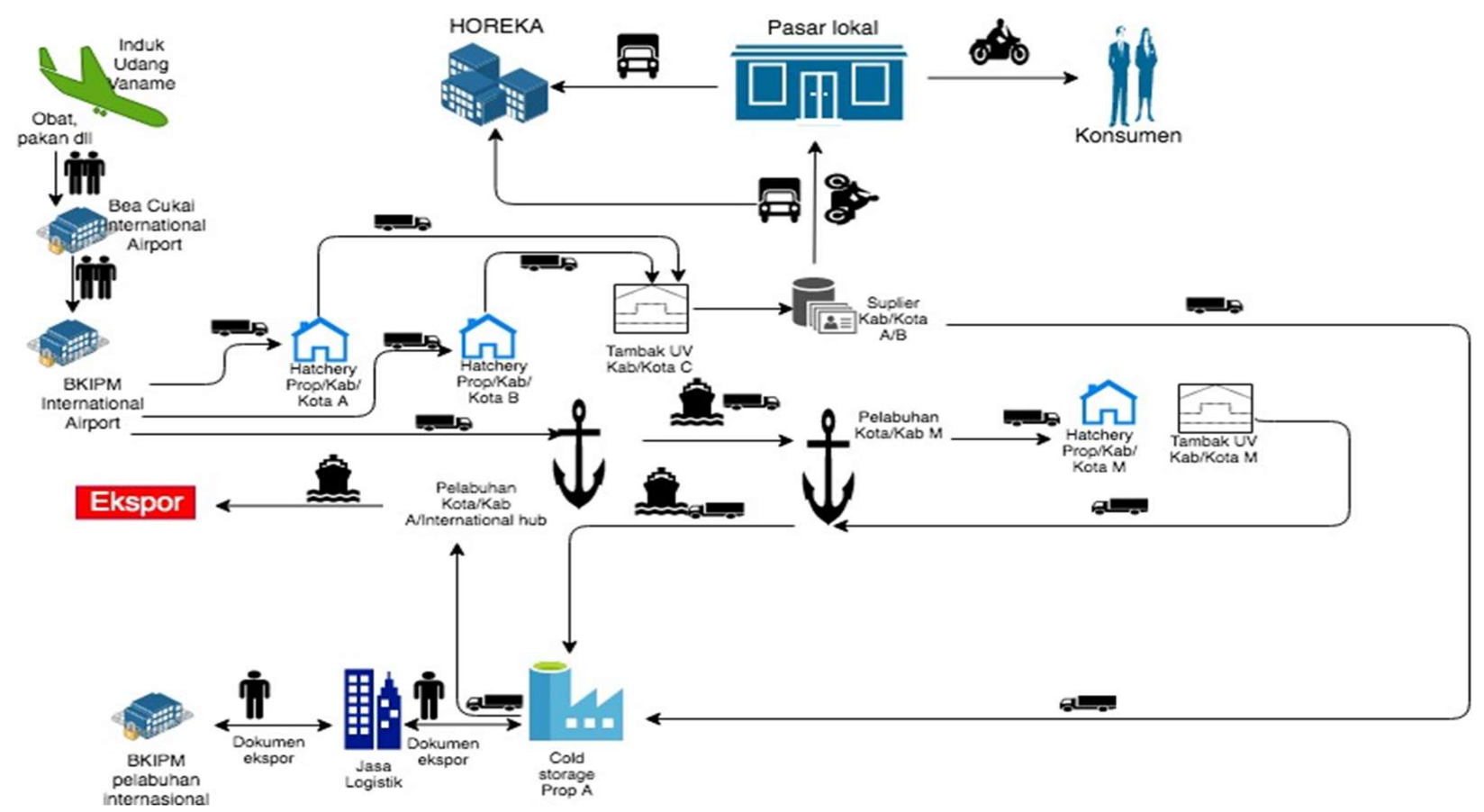

Gambar 4. Model umum skema freight logistic udang vanamei. Figure 4. General Model of Freight Logistic Scheme Of Vannamei shrimp 
yang tinggi; serangan hama dan penyakit udang, pencemaran yang mempengaruhi kualitas lingkungan perikanan budi daya.

Permasalahan utama pada budi daya udang vanamei adalah terkait dengan pembenihan, pembesaran, dan pemasaran. Permasalahan pembenihan terjadi pada dua hal utama yaitu; induk udang vanamei masih mengandalkan produksi dari Hawaii, Amerika Serikat, dan waktu tunggu pemesanan benih udang di pembenihan membutuhkan waktu minimal 1 bulan sebelumnya. Sampai saat ini, penyedia induk udang vanamei cenderung single seller yaitu melalui PT. Konabai yang mengimpor induk dari Hawai. Permintaan induk udang dari Indonesia yang semakin bertambah tiap tahunnya tidak diikuti dengan penambahan daerah pasokan induk udang. Kondisi ini membuat induk yang diimpor kadang-kadang menghasilkan benih yang kurang berkualitas. Permasalahan pada pembesaran udang terjadi terkait dengan penyakit terutama Early Mortality Syndrome yang masih menjadi kendala utama pada pembudi daya. Sementara itu, bahan baku yang relatif masih sangat terbatas untuk memenuhi kebutuhan unit pengolahan ikan (UPI) dan harga yang masih tergantung pada supplier. Permasalahan yang sama juga dihadapi oleh para pembudi daya di Jawa Timur.

Dalam rangka pemenuhan kebutuhan konsumen yang semakin meningkat, anggota rantai pasokan udang vanamei dituntut untuk memiliki keunggulan kompetitif yang tinggi sehingga dapat memberikan produk yang berkualitas dan pelayanan yang memuaskan kepada konsumen (Apriani et al., 2019; Isamu, et al., 2018). Rantai pasokan udang vanamei memiliki kendala dalam menghasilkan keuntungan seperti pada Tabel 4. Sumber induk yang berasal dari luar negeri serta lokasi produsen benih yang jauh dari lokasi budidaya menyebabkan kegiatan dan hasil produksi tidak efisien dan berimplikasi pada peningkatan biaya (Brown, 2003). Oleh karena itu, pengaturan rantai pasokan sangat diperlukan dengan mempertimbangkan keseluruhan kegiatan dari bahan baku, proses pengirimannya sampai ke pelanggan maupun proses pengembalian produk (return). Penyakit pada udang vanamei serta harga pakan yang tinggi menjadi kendala yang dihadapi oleh pembudidaya pada sub sistem pembesaran udang.

Proses bisnis rantai dapat menjelaskan sistem ketertelusuran rantai pasokan udang vanamei. Sistem traceability dalam rantai pasok memungkinkan pelaku usaha dalam rantai untuk menelusuri penyebab terjadinya risiko kerugian pada rantai pasokan udang vanamei. Risiko tersebut juga terkait dengan sifat produk udang vanamei yang mudah rusak, seperti yang disampaikan Al-Busaidi et al. (2016) bahwa produk makanan laut dalam rantai pasok seringkali mengalami proses penanganan dan distribusi yang lama sebelum mencapai konsumen, dan sering kali mudah rusak dan keamanannya terganggu jika tidak dikontrol dengan baik. Masalah yang umum dihadapi oleh banyak negara berkembang termasuk Indonesia.

Hubungan proses bisnis tersebut ditentukan pula oleh kekuatan posisi tawar (bargaining position) antar pelaku rantai pasokan yang pada akhirnya menentukan harga produk udang vanamei maupun

Tabel 4. Permasalahan dalam pembenihan, pembesaran dan Pemasaran.

Table 4. Issues on Haatching, Farming and Marketing..

\begin{tabular}{|c|c|c|}
\hline No & Sub bidang/Sub filed & Permasalahan/the problems \\
\hline 1 & Pembenihan/Hatching & $\begin{array}{l}\text { - Indukan udang vanamei masih mengandalkan produksi dari Hawaii, } \\
\text { Amerika Serikat/ Broodstock of vanamei shrimp relied on production } \\
\text { from Hawaii, United States. } \\
\text { - Waktu tunggu pemesanan benih udang di hatchery membutuhkan } \\
\text { waktu minimal } 1 \text { bulan sebelumnya/ Shrimp juvenile order needs one } \\
\text { month in advance. }\end{array}$ \\
\hline 2 & Pembesaran/Rearing & $\begin{array}{l}\text { - Penyakit Early Mortality Syndrome/ Early Mortality Syndrome Disease. } \\
\text { - Pakan yang menyerap biaya produksi paling tinggi/ The highest } \\
\text { production cost is feed purchasing. }\end{array}$ \\
\hline 3 & Pemasaran/Marketing & $\begin{array}{l}\text { - Bahan baku yang relatif masih sangat terbatas untuk memenuhi } \\
\text { kebutuhan/ Limited raw material for farming needs } \\
\text { - Harga pakan ditentukan oleh pemasok/ Feed prices are decided by } \\
\text { the supplier. }\end{array}$ \\
\hline
\end{tabular}

Sumber: Zamroni et al. (2019) 
harga input yang digunakan dalam rantai pasokan. Penentu harga udang vanamei ditentukan oleh UPI khususnya untuk udang ukuran ekspor (size $>100$ ekor/kg). Harga udang konsumsi lokal sangat dipengaruhi oleh ketersediaan pasokan udang di pasar (Pattola et al., 2019). Harga udang akan cenderung turun pada saat musim panen udang, dan sebaliknya harga udang akan meningkat ketika terjadi banyak gagal panen.

Menurut Yusuf et al. (2020), pembudi daya udang di Provinsi Sulawesi Selatan menghadapi permasalahan utama pada pembenihan dan pemasaran. Permasalahan pada pembenihan terkait adanya sebagian pembenihan yang tidak tersertifikasi yang akan membuat benur-benur tidak berkualitas, sebagian backyard belum menerapkan sistem pengolahan dengan biosecurity dan hanya melihat kuantitas saja. Permasalahan di pemasaran masih sama dengan yang terjadi di Jawa Barat dan Jawa Timur dan ada keterikatan pembudi daya dengan supplier terutama pada pemenuhan kebutuhan pembudi daya (contoh: es), sehingga pembudi daya tidak perlu membeli es di supplier.

Pengelolaan limbah juga masih menjadi hambatan untuk memproduksi udang vanamei dengan kualitas yang baik. Pembudi daya udang vanamei belum semua melaksanakan aturan sertifikat cara budi daya ikan yang baik (CBIB) yang seharusnya wajib dilakukan oleh setiap pembudi daya udang. Kondisi tersebut akan merugikan para pembudi daya dan lingkungan. Namun, pembudi daya masih banyak yang tidak memperhatikan dengan serius dan kesadaran terhadap risiko masih rendah.

\section{KESIMPULAN DAN REKOMENDASI KEBIJAKAN}

\section{Kesimpulan}

Rantai pasok udang vanamei di Indonesia bisa digolongkan 3 bagian yaitu pasokan, distribusi dan konsumen dengan jalur rantai pasok yang masih pendek untuk sampai kepada unit pengolahan ikan (UPI). Namun, rantai pasokan dapat dikatakan belum efektif jika mempertimbangkan keseluruhan kegiatan dari proses memperoleh bahan baku, proses pengiriman sampai ke pelanggan maupun proses pengembalian produk (return).

Kinerja rantai pasok terdiri atas 2 (dua) indikator yaitu efektifitas dan efisiensi. Indikator efektifitas yaitu melihat ketersediaan pasokan pada lokasi riset, yang menunjukkan bahwa
Provinsi Nusa Tenggara Barat (NTB) merupakan daerah pasokan udang terbesar, disusul oleh Jawa Barat, Jawa Timur dan Sulawesi Selatan. Indikator efisiensi dilihat dari dua indikator yaitu disparitas harga dan margin harga. Provinsi Bali memiliki disparitas harga antar waktu terbesar yaitu sebesar $16 \%$. Berdasarkan indikator disparitas harga antar daerah, Provinsi NTB memiliki disparitas harga tertinggi yaitu sebesar 67\%. Pedagang kecil merupakan simpul yang memiliki margin harga terkecil yaitu sebesar 3\%, disusul dengan pengecer sebesar 22\%. Sementara pada konsumen UPI, pedagang kecil memiliki margin harga terkecil yaitu $4,3 \%$ dan pedagang pengumpul sebesar $12,5 \%$.

Permasalahan rantai pasok udang vanamei mulai dari produsen benih sampai ke konsumen akhir telah menyebabkan kegiatan dan hasil produksi tidak efisien, sehingga berimplikasi pada peningkatan biaya. Proses bisnis rantai pasok dapat menjelaskan sistem ketertelusuran dalam rantai pasokan udang vanamei mulai dari pembenihan, pembesaran dan pemasaran dan sangat dipengaruhi oleh kekuatan posisi tawar (bargaining position) antar pelaku rantai pasok.

\section{Rekomendasi Kebijakan}

Rantai pasok komoditas udang akan efektif dan efisien apabila indikator-indikator yang ada seperti ketersediaan, disparitas harga baik antar waktu maupun antara daerah, dan margin harga menunjukkan kinerja yang baik. Daerah-daerah produksi udang akan menjadi daerah pasokan udang yang akan memenuhi permintaan baik UPI maupun konsumsi domestik. Disparitas harga disebabkan karena berbagai masalah yang terjadi yaitu dari pemenuhan kebutuhan benih dan pakan sampai pada pemasaran hasil produksi udang. Oleh karena itu, pentingnya dukungan sistem logistik yang baik dari sisi trade logistik dan freight logistik yang di dalamnya memuat sistem perdagangan, sistem penyimpanan dan sistem transportasi terutama membuat klaster baru daerah yang memproduksi benih udang vanamei dan memperoleh akses induk udang vanamei secara langsung.

Ke depan, efektifitas rantai pasok dan logistik udang vanamei dapat dilakukan dengan membuat rayonisasi kawasan integrasi industri udang vanamei. Berdasarkan lokasi yang kita survey dan analisis kinerja rantai pasok, pembentukan klaster kawasan integrasi industri udang vanamei dapat dilakukan di 4 tempat, yaitu 1) klaster 1 yang meliputi Provinsi Bali dan Provinsi Nusa Tenggara 
Barat; 2) Klaster 2 yang meliputi Provinsi Jawa Timur; 3) Klaster 3 yang meliputi Provinsi Sulawesi Selatan, Provinsi Sulawesi Barat dan Provinsi Gorontalo; 4) Klaster 4 yang meliputi Provinsi DKI. Jakarta, Provinsi Jawa Barat, Provinsi Banten, dan Provinsi Lampung. Keempat klaster tersebut dipilih dari infrastruktur bandara (internasional) dan pembenihan untuk menjaga kestabilan pasokan induk dan benih udang vanamei. Sementara itu, klaster 1 memerlukan unit pengolahan ikan (UPI) atau cold storage untuk menampung hasil budidaya udang vanamei dan mendorong ekspor langsung dari klaster 1. Oleh karena itu, memberi kesempatan kepada pihak swasta untuk membuka pembenihan baru di kawasan yang masih kekurangan stok benih, dan membuka dan atau merevitalisasi tambak-tambak udang yang kurang produktif.

Pemerintah perlu menjamin jangkauan distribusi benih ke seluruh wilayah NKRI dengan metode rayonisasi, serta jangkauan distribusi udang ke UPI atau pabrik dengan metode rayonisasi. Selain itu perlu disertai dengan langkah pengendalian dengan cara memastikan implementasi CBIB dan CPIB di daerah produksi, pelaporan data yang terkait pembenihan dan pembesaran udang, dan meregistrasi pelaku usaha (pembudidaya, pedagang kecil dan pedagang besar). Pemerintah juga harus melakukan evaluasi dan pembenahan terhadap sistem logistik yang ada, baik dari fasilitas penyimpanan, moda transportasinya, sarana transportasi, inter-moda transportasi serta simpul transportasi sehingga diharapkan akan menghasilkan sistem logistik yang efisien dan efektif.

\section{UCAPAN TERIMA KASIH}

Ucapan terima kasih disampaikan kepada semua pihak yang telah mendukung terlaksananya riset ini terutama Balai Besar Riset Sosial ekonomi Kelautan dan Perikanan dan para peneliti pada kegiatan riset sistem logistik budi daya tahun 2019 sehingga makalah ini terselesaikan. Kami juga menyampaikan apresiasi kepada tim reviewer yang telah memberikan masukan secara konstruktif untuk perbaikan makalah ini.

\section{PERNYATAAN KONTRIBUSI PENULIS}

Dengan inikami menyatakan bahwakontribusi masing-masing penulis terhadap pembuatan karya tulis adalah: Achmad Zamroni sebagai kontributor utama, Risna Yusuf sebagai kontributor anggota,
Tenny Apriliani sebagai kontributor anggota. Penulis menyatakan bahwa telah melampirkan surat pernyataan kontribusi penulis.

\section{DAFTAR PUSTAKA}

Al-Busaidi M.A., Jukes D.J. \& S. Bose. (2016). Seafood safety and quality: An analysis of the supply chain in the Sultanate of Oman. Food Control (59);651-662. Doi: 10.1016/j. foodcont.2015.06.023.

Apriani, H., C.I. Erliana \& M. Zakaria (2019). Analisis Supply Chain Management (Scm) Udang VanameiDi Desa Teupin Pukat Kabupaten Aceh Timur. SNTI 2019, Lhokseumawe 14-15 Oktober 2019 ISSN : 23387122.

Batker, D. K. \& Genciano, G. J. (2003). Anti-Economics: The Realities and Fallacies of Shrimp Aquaculture. In: The Blues of a Revolution: The Damaging Impacts of Shrimp Farming. Barnhizer, D. and De la Torre, I. Eds.

Brown, W. J. (2003). Agribusiness Cases in Supply Chain Management. Paper. IFMA Congress.

Champion, S.C. dan A.P. Fearne (2001). Supply Chain Management: A First Principles Consideration of Its Application to Wool Marketing. Jurnal. Wool Technology of Sheep Breeding Vol. 49 (3). Hal. $222-236$.

Deswati, R. H., L. Rosyidah, \& T. Apriliani (2020). Pengaruh Manajemen Rantai Pasok Terhadap Performa Usaha Budi Daya Udang VanameiDi Provinsi Bali Dan Jawa Timur. Buletin IImiah Marina Sosial Ekonomi Kelautan Dan Perikanan, p-ISSN: 2502-0803 e-ISSN: 2541-2930

Elizabeth, R., (2019). Pengembangan Agribisnis Dan Pengolahan Mendukung Pensejahteraan Petani Cabe Merah. Jurnal Pemikiran Masyarakat IImiah Berwawasan Agribisnis. Juli 2019. 5(2): 413-435

Ha, T.T.T., Bush, S.R. \& van Dijk, H. (2013). The cluster panacea? Questioning the role of cooperative shrimp aquaculture in Vietnam. Aquaculture, 388-391 (1). 89-98. Doi: 10.1016/j. aquaculture.2013.01.011

Hadie, W., \& Hadie, L. E. (2017). Analisis Sistem Budidaya Untuk Mendukung Kebijakan Keberlanjutan Produksi Udang. Jurnal Kebijakan Perikanan Indonesia, 9(1), 51-60

Holmström, J. \& Partanen, J. (2014). Digital manufacturing-driven transformations of service supply chains for complex products. Supply Chain Management: An International Journal, 19(4), 421-430.

Isamu, I., Salam, I., \& Yunus, L. (2018). Analisis Kelayakan Usaha Budidaya Udang VanameiPola Tradisional Plus di Kecamatan Samaturu 
Kabupaten Kolaka. Jurnal Sosio Agribisnis (JSA), 3(1), 41-48. http://ojs.uho.ac.id/index.php/JSA/ article/view/7400/5407

Kanji, N. \& Barrientos, S. (2002). Trade Liberalization, Poverty and Livelihoods: Understanding the Linkages. A Review for the Africa Policy and Economics Department. Department for International Development, UK. IDSWorking Paper 159. Institute of Development Studies.

Lambert, D., Cooper, M. \& Pagh, J. (1998). Supply chain management: implementation issues and research opportunities. The International Journal of Logistics Management, 9(2), 1-19.

Lee, T.N., Bregt, A.K., van Halsema, G.E., Hellegers, P.J.G.J. \& Nguyen, L.D. (2018). Interplay between land-use dynamics and changes in hydrological regime in the Vietnamese Mekong Delta. Land Use Policy (73) 269-280.

Liu, P., Samuel H.H., Abriham M., Heng Z., \& Liang H. (2013). "The Impact of Additive Manufacturing in the Aircraft Spare Parts Supply Chain: Supply Chain Operation Reference (SCOR) Model Based Analysis". Production Planning dan Control: The Management of Operations, DOI: 10.1080/09537287.2013.808835.

Nazir, M. (1988). Metode Penelitian. Ghalia Indonesia. Jakarta.

Govindan, K., Soleimani, H., \& Kannan, D. (2015). Reverse logistics and closed-loop supply chain: A comprehensive review to explore the future. European Journal of Operational Research, 240(3), 603-626. https://doi.org/10.1016/j. ejor.2014.07.012

Masi, D., Day, S., \& Godsell, J. (2017). Supply chain configurations in the circular economy: A systematic literature review. Sustainability (Switzerland), 9(9). https://doi.org/10.3390/su9091602

Miller, R. (2018). "Walmart is betting on the blockchain to improve food safety", Tech Crunch, Sept 24, 2018: https://techcrunch.com/2018/09/24/ walmart-is-betting-on-the-blockchain-to-improvefood-safety/.

Pattola, E. V., Ola, L. O. L, \& Piliana, W. O. (2019). Analisis Rantai Pemasaran Udang Vanamei(Litopenaeus vannamei) Beku (Studi Kasus PT. Yanagi Histalaraya PPS Kendari). Jurnal Sosial Ekonomi Perikanan FPIK UHO, 4(2), 161-169. http://ojs.uho.ac.id/index.php/JSEP/article/ view/8402/6158.

Ramirez, M., Clarke, I. \& Klerkx, L. (2018). Analysing intermediary organizations and their influence on upgrading in emerging agricultural clusters. Environ. Plan. A: Econ. Space 50, 1314-1335.

Song J.M., Sung, J. \& Part T. (2019). Aplication Blockchain to Improve Supply Chain Traceability. $7^{\text {th }}$ International Conference on Information Technology and Quantitative Management (ITQM 2019). Procedia Computer Science 162, 119-122.

Tajerin, Muhadjir \& Deswati, R.H. (2015). Model Pengembangan Sistem Logistik Ikan Nasional Terintegrasi Mp3ei Dan Sistem Transportasi Melalui Pendekatan Pengadaan Stok Ikan. Balai Besar Riset Sosial Ekonomi Kelautan dan Perikanan, Badan Riset dan Sumberdayya Manusia Kelautan dan Perikanan, Jakarta.

Van Hoek, R., (1998). Measuring the unmeasurable measuring performance in the supply chain. Supply Chain Management: An International Journal 3(4), 187-192.

Yusuf, R., Rosyidah, L. Zamroni, A. \& Apriliani, T. (2020). Rantai Pasok Dan Sistem Logistik Udang VanameiDi Kabupaten Pinrang, Provinsi Sulawesi Selatan. Buletin IImiah Marina Sosial Ekonomi Kelautan Dan Perikanan, 6(1) p-ISSN: 2502-0803 e-ISSN: 2541-2930

Zamroni, A., R. Yusuf, T. Apriliani, Asnawi, R.H. Deswanti, B.V. Indah \& L. Rosyidah (2019). Riset Model Penerapan Sistem Logistik Perikanan Budi Daya serta Penggunaan DSS untuk Perikanan Budi Daya Berkelanjutan. Laporan Teknis. BBRSEKP. Jakarta. 